\title{
Phylogenetic Analysis of New Isolates of Cucumber mosaic virus from Iran on the Basis of Different Genomic Regions
}

\author{
Sevil Nematollahi ${ }^{\mathbf{*}}$, Nemat Sokhandan-Bashir ${ }^{2}$,Farshad Rakhshandehroo ${ }^{1}$ and Hamid Reza Zamanizadeh ${ }^{1}$ \\ ${ }^{1}$ Department of Plant Pathology, Islamic Azad University, P.O. Box 14515-775, Tehran, Iran \\ ${ }^{2}$ Plant Protection Department, University of Tabriz, 29 Bahman Blvd., Tabriz 51664 Iran
}

(Received on June 10, 2012; Revised on July 31, 2012; Accepted on August 5, 2012)

\begin{abstract}
Molecular characterization of Cucumber mosaic virus (CMV) was done by using samples from tomato and cucurbitaceous plants collected from different locations in the northwest region of Iran. After screening by enzyme-linked immunosorbent assay, $91 \mathrm{CMV}$-infected samples were identified. Biological properties of eight representative isolates were compared with each other revealing two distinct phenotypes on squash and tomato plants. Phylogenetic analyses based on nucleotide sequences of the coat protein (CP), movement protein (MP) and $2 b$ of the new isolates, together with that of previously reported isolates, led to the placement of the Iranian isolates in subgroups IA and IB according to $C P$ and MP genes, but in subgroup IA according to the $2 \mathrm{~b}$ gene. These data suggest that reassortment may have been a major event in the evolution of CMV in Iran, and that the Iranian isolates are derived from a common recent ancestor that had passed through a bottleneck event.
\end{abstract}

Keywords : CMV, CP, genotype, MP, phylogenetic analysis, subgroup, $2 \mathrm{~b}$

Cucumber mosaic virus (CMV) is the type member of the genus Cucumovirus in the family Bromoviridae. CMV has a wide host range in 85 distinct families of dicotyledonous and monocotyledonous angiosperms (Bujarski et al., 2012). The virus is transmitted by some 80 aphid species belonging to 33 genera in a non- persistent non- circulative manner (Palukaitis and Garcia-Arenal, 2003). CMV causes disease outbreaks in tomato, pepper or cucurbits which result in great economic losses for many countries (Gallitelli, 2000). CMV has three single-stranded plus-sense RNAs (RNA13 ) that code for five functional proteins [1a, 2a, 2b, 3a and coat protein (CP)]. Proteins $1 \mathrm{a}$ and $2 \mathrm{a}$, encoded by RNA1 and RNA2, respectively, are components of the replicase complex (Hayes and Buck, 1990). The RNA3- encoded proteins, $3 \mathrm{a}$ [movement protein (MP)] and $\mathrm{CP}$ are involved

\footnotetext{
*Corresponding author.

Phone) +98(411)6373339, FAX) +98(411)6370009

E-mail)nematollahi2001@yahoo.com
}

in viral movement. The $\mathrm{CP}$ is translated from the subgenomic RNA4 and required for encapsidation, longdistance movement and transmission by aphids (Boccard and Baulcombe, 1993; Perry et al., 1994; Shi et al., 2002). Protein $2 \mathrm{~b}$ is expressed from RNA 4A, a subgenomic RNA derived from RNA2, is involved in the long-distance movement of CMV in the plant (Soards et al., 2002) and functions as a suppressor of RNA silencing (Ding et al., 1994; Li et al., 1999). Many strains and isolates of CMV have been characterized on the basis of symptoms and host range (Choi et al., 2005; Huppert et al., 2002; Palukaitis and Garcia-Arenal, 2003) and often, differences in such phenotypes were mapped to the genomic RNAs that code for the CP (Shintaku et al., 1992; Sugiyama et al., 2000; Suzuki et al., 1995), MP (Choi et al., 2005) or 2b protein (Du et al., 2007; Shi et al., 2002; Lewsey et al., 2009, 2010).

Phylogenetic studies have resulted in classification of CMV isolates to three subgroups designated subgroup IA (S-IA), subgroup IB (S-IB) and subgroup II (S-II) (Palukaitis et al., 1992; Roossinck et al., 1999). Subgroup I (S-I) and SII isolates have $75 \%$ nucleotide (nt) sequence identity whereas S-IA and S-IB are more closely related and share 92-95\% identity (Roossinck, 2001). In a previous study we detected members of S-IA in cucurbits in Iran and analyzed their phylogenetic positions based on the $\mathrm{CP}$ sequences (Bashir et al., 2008). Here, we studied some of the biological properties of eight representative CMV isolates on different hosts. In addition to amplification of the MP and CP genes from the collected samples, a specific pair of primers was designed to amplify the $2 \mathrm{~b}$ gene from Iranian isolates of CMV. The three amplified genomic regions were cloned, sequenced and their phylogenetic relationships were determined. Also, the genotypes of eight representative isolates were investigated in relation to their symptoms on experimental host plants.

Leaves of tomato and cucurbitaceous plants showing symptoms similar to those caused by CMV, were collected from 17 locations in the Ardabil, East Azarbaijan, and West Azarbaijan provinces during 2009-2010. Eight representative $\mathrm{CMV}$ isolates from distinct geographical locations 


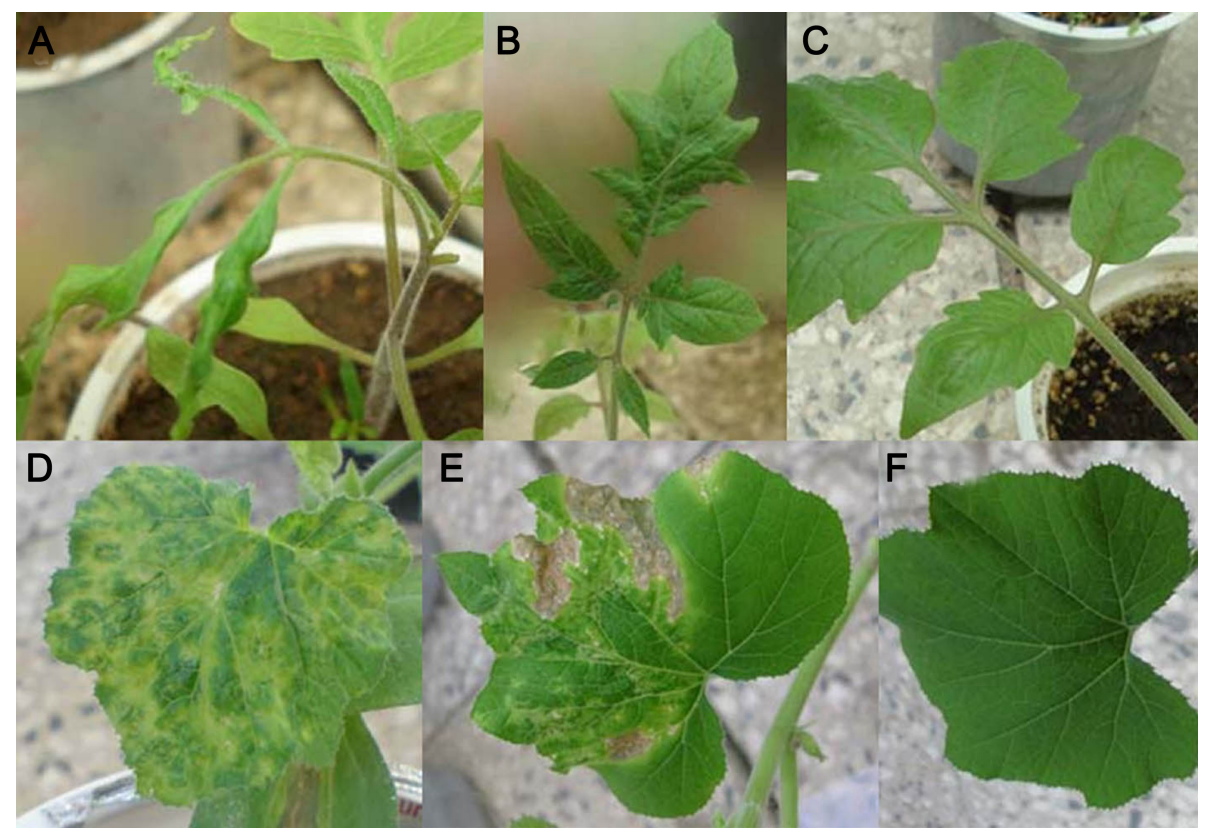

Fig. 1. Symptoms of representative isolates of Cucumber mosaic virus (CMV) from Iran on tomato (A, B, C) and squash (D, E, F) 14 days post inoculation. Severe shoestring by isolate Khn1 (A), mild shoestring by Bon175 (B), mosaic by Bon175 (D), necrosis by Khn1 (E), mock inoculations $(\mathrm{C}, \mathrm{F})$.

were selected to investigate their biological properties. Sap from the infected samples was rubbed on Carborundumdusted leaves of Chenopodium quinoa, Cucurbita pepo cv. Ps, Nicotiana benthamiana, Nicotiana tabacum cvs. Coker347, Virginia and Xanthi and Solanum lycopersicum cv. Supper using 0.1 M PBS (pH 7.2).

Leaves from collected samples were tested with doubleantibody sandwich (DAS)-ELISA (Clark and Adams, 1977). The presence of CMV was detected in 91 out of 339 screened samples with virus like symptoms from different locations in North-West Iran by DAS-ELISA. The infection rates for tomato, cucumber, squash and muskmelon plants were $36 \%, 30 \%, 12 \%$ and $16 \%$, respectively. The pre- dominant symptom associated with isolates Bon175, Mgh91 and Jol186 on squash was severe mosaic and in the case of Mgh191, mild mosaic. Isolates Ajs4, Bas3, Esf172 and Khn1 showed necrosis on squash plants $14 \mathrm{dpi}$, which resulted in death of plants $30 \mathrm{dpi}$, whereas isolates Bon175, Mgh91 and Mgh191 did not show necrosis even at 35 dpi. In the case of Jol186 only non-lethal necrosis was observed by 35 dpi. Shoestring, a prevalent symptom on tomato, was more severe with isolates Ajs4, Bas3, Esf172 and Khn1, than isolates Bon175 and Mgh91 (Fig. 1A, 1B). Symptoms of Ajs4, Bas3, Esf172 and Khn1, were similar on tobacco cultivars and $N$. benthamiana including mosaic with dark green areas. Isolates including Bon175, Mgh91, Mgh191

Table 1. Characteristics of primers used to amplify different genomic regions of CMV

\begin{tabular}{|c|c|c|c|}
\hline Primer name & Position & Expected size & Nucleotide sequence $^{c}$ \\
\hline $\begin{array}{l}\text { 2bIR-F } \\
\text { 2bIR-R }\end{array}$ & $\begin{array}{l}2226-2252(2 b)^{a} \\
2851-2874(2 b)\end{array}$ & 649 & $\begin{array}{l}\text { 5'-TTYGARTTGAAATACARGAAGTCYGGG-3' } \\
\text { 5'-CCGTAAGCTGGATGGACAACCCG-3' }\end{array}$ \\
\hline $\begin{array}{l}\text { CMVCPf } \\
\text { CMVCPr }\end{array}$ & $\begin{array}{l}1149-1161(\mathrm{CP})^{\mathrm{b}} \\
1998-2015(\mathrm{CP})\end{array}$ & 867 & $\begin{array}{l}\text { 5'-GCTTCTCCGCGAG-3' } \\
\text { 5'-GCCGTAAGCTGGATGGAC-3' }\end{array}$ \\
\hline $\begin{array}{l}\text { M1-forward } \\
\text { M2-reverse }\end{array}$ & $\begin{array}{l}119-138(\mathrm{MP})^{\mathrm{d}} \\
938-959(\mathrm{MP})\end{array}$ & 841 & $\begin{array}{l}\text { 5'-CATGGCTTTCCAAGGTACCAG-3' } \\
\text { 5'-CTAAAGACCGTTAACCACCTGC-3' }\end{array}$ \\
\hline $\begin{array}{l}18 \mathrm{~s} 1 \\
18 \mathrm{~s} 2\end{array}$ & $\begin{array}{l}357-375\left(18 \mathrm{~S} \mathrm{DNA}^{\mathrm{e}}\right) \\
798-817(18 \mathrm{~S} \text { DNA) }\end{array}$ & 461 & $\begin{array}{l}\text { 5'-AACGGCTACCACATCCAAG-3' } \\
\text { 5'-TCATTACTCCGATCCCGAA-3' }\end{array}$ \\
\hline
\end{tabular}

${ }^{a}$ Nucleotide positions correspond to the genomic RNA2 of CMV-Fny

${ }^{b}$ Nucleotide positions correspond to the genomic RNA3 of CMV-Q (Rizos et al., 1992)

${ }^{\mathrm{c}} \mathrm{R}=\mathrm{A}$ or $\mathrm{G} ; \mathrm{Y}=\mathrm{C}, \mathrm{T}$

${ }^{\mathrm{d}}$ Nucleotide positions correspond to the genomic RNA3 of CMV-Fny (Lin et al., 2004)

${ }^{\mathrm{e}}$ Nucleotide positions correspond to18S ribosomal DNA, in the accession JQ612131.1 
and Jol186 showed mild mosaic and sometimes no visible symptoms on these plants.

Total RNA from leaves of infected samples was extracted according to Rowhani et al. (1993) with minor modifications as reported previously (Bashir et al., 2008). Three sets of primers were used to amplify different genomic regions of CMV (Table 1). For isolation of the $2 \mathrm{~b}$ gene a pair of new specific primers was designed by the use of Oligo ver. 5 (Rychlik, 1994). Reverse transcription was carried out with 0.3 pmol $2 \mathrm{~b}$, MP or CP specific reverse primers or 5 pmol random hexamer primer (Fermentas, Lithuania) in $20 \mu \mathrm{l}$ reverse transcription mix. Using specific primers for CP, all the ELISA positive samples (91 samples) were tested with RT-PCR, but amplification with the $2 \mathrm{~b}$ and MP primers was only performed on 45 samples from different locations which showed different symptoms on the original host plants. The thermocycle program for amplification of the MP or CP cDNAs included 1 cycle of $94^{\circ} \mathrm{C}$ for $1 \mathrm{~min}, 30$ cycles of $94^{\circ} \mathrm{C}$ for $30 \mathrm{sec}, 50^{\circ} \mathrm{C}$ for 30 sec and $72^{\circ} \mathrm{C}$ for $1 \mathrm{~min}$, and a final cycle of polymerization at $72^{\circ} \mathrm{C}$ for $5 \mathrm{~min}$. Amplification of the $2 \mathrm{~b}$ cDNA was achieved with a similar thermocycle profile, but the annealing was done at $65^{\circ} \mathrm{C}$. RT-PCR with the CP primers on the 91 ELISA-positive samples resulted in amplification of an expected $867 \mathrm{bp}$ fragment from all of them (data not shown). The expected 649 or $841 \mathrm{bp}$ fragment was amplified from the samples tested with the $2 \mathrm{~b}$ or MP primers, respectively (Fig. 2A, 2B).

PCR products resulting from the use of the CP primers were digested with the cutter $M s p$ I as described previously (Bashir et al., 2008). Digestion of the amplified CP cDNA with MspI produced two fragments with sizes about 537 and $335 \mathrm{bp}$ from each isolate (data not presented). The restriction analysis as a method for typing CMV isolates (Rizos et al., 1992) showed that all the Iranian CMV isolates belonged to $\mathrm{S}-\mathrm{I}$. Our previous studies on $\mathrm{CMV}$ isolates from Iran have also shown the frequent occurrence of the S-I in the country. While most S-IB isolates are distributed in Asia, S-IA and S-II isolates possess worldwide distribution (Palukaitis and Zaitlin, 1997; Roossinck, 2001).

For subsequent cloning and sequencing procedure seventeen representative PCR products of the $2 \mathrm{~b}$ gene, 12 of the $\mathrm{CP}$ and 10 of the MP gene were selected based on geographical location of the original samples as well as the host plants. Each PCR product ( $20 \mathrm{ng}$ each) was ligated into the pTZ57R/T vector (Fermentas, Lithuania). Escherichia coli $\mathrm{DH} 5 \alpha$ was made competent according to Chung et al. (1989) and transformed with the ligation mix. The selection and screening were performed as described previously (Bashir et al., 2006). The sequences reported in this paper were submitted to GenBank and assigned the accession numbers JX025971-JX026001, JX000232, and JX00023. Multiple nucleotide sequence alignments of the Iranian isolates with the previously reported CMV strains/isolates (Table 2) were performed by the use of GeneDoc (Nicholas et al., 1997).

The ratio of non-synonymous nucleotide diversity to synonymous nucleotide diversity $[\mathrm{Pi}(\mathrm{a}) / \mathrm{Pi}(\mathrm{s})]$ was estimated by the use of DnaSP version 5.10.01 (Librado and Rozas, 2009). The value of this ratio is $1,<1$ and $>1$ under neutral, negative (purifying selection) and positive (directional selection), respectively. The ratio values were determined for different sections of the genomic regions by the use of

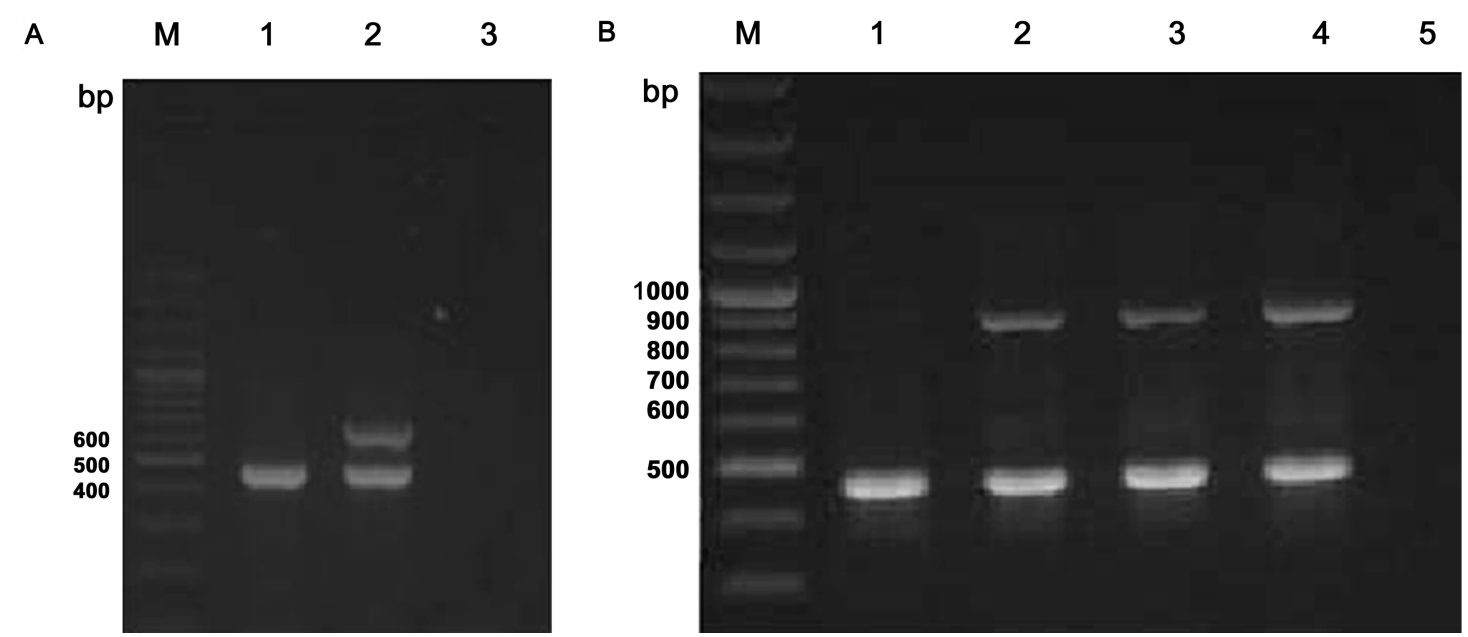

Fig. 2. Agarose gel electrophoresis of DNA fragments amplified from some infected and non-inoculated plants by RT-PCR with the $2 b$ (A) and MP (B) primers and 18S rDNA primers as the internal control (461 bp). (A) 100 bp DNA ladder (lane M), non-inoculated control (lane 1), a representative amplification of a 649 bp DNA from isolate Mgh91 (lane 2), amplification with no template (lane 3). (B) $100 \mathrm{bp}$ DNA ladder (lane M), non-inoculated control (lane 1), amplification of an 841 bp fragment from isolates Khn1 (lane 2), Mgh91 (lane 3), Bas3 (lane 4), and without template (lane 5). 
Table 2. Accession numbers, abbreviations, host and geographical origins of CMV strains/isolates used for the phylogenetic analyses in this study

\begin{tabular}{|c|c|c|c|c|}
\hline \multirow{2}{*}{ Isolate } & \multicolumn{2}{|c|}{ Accession No. } & \multirow{2}{*}{ Host } & \multirow{2}{*}{ Origin } \\
\hline & RNA2 & RNA3 (MP/CP) & & \\
\hline CK54 & - & AF523351 (CP) & Cucurbita pepo & USA \\
\hline MD284 & - & AF523343 (CP) & Solanum lycopersicum & USA \\
\hline CMV-G10 & - & AY541691 (CP) & S. lycopersicum & Egypt \\
\hline $\mathrm{Mi}$ & AB188229 & AB188230 & Zingiber mioga & Japan \\
\hline Kor & - & L36251 & - & South Korea \\
\hline Pepo & $\mathrm{AB} 124835$ & AF103991 & C. реро & Japan \\
\hline Z & - & AB369269 & Nicotiana benthamiana & South Korea \\
\hline $\mathrm{Z1}$ & - & GU327368 & C. реро & South Korea \\
\hline Licb & AB506799 & AB506800 & Lilium longiflorum & South Korea \\
\hline Fuka4-4 & $\mathrm{AB} 188232$ & AB188233 & Cucumis sativus & Japan \\
\hline $\mathrm{Cm} 95$ & $\mathrm{AB} 188235$ & Ab188236 & N. tabacum & Japan \\
\hline $\mathrm{Y}$ & D12538 & D12499 & N. tabacum & Japan \\
\hline D8 & $\mathrm{AB} 179765$ & AB004781 & Raphanus sativus & Japan \\
\hline Mf & AJ276480 & $\mathrm{AJ} 276481$ & Melandryum firmum & South Korea \\
\hline ZM & JN180310 & JN180311 & Zea mays & South Korea \\
\hline RT52 & FR827863 & AJ810258(CP) & C. реро & USA \\
\hline FNY & NC002035 & D10538 & Cucumis melo & USA \\
\hline GD & - & HQ916354 & Oilseed pumpkin & Austria \\
\hline Ri-8 & AM183118 & AM183119 & S. lycopersicum & Spain \\
\hline As & - & AF013291 & - & South Korea \\
\hline $\mathrm{K}$ & - & AF127977 & - & USA \\
\hline SD & D86330 & AB008777 & N. tabacum & China \\
\hline $\mathrm{Ca}$ & AY429433 & AY429432 & Arachis hypogaea & China \\
\hline ND2 & EU414799 & EU414789/EU41486 & P. hybrida & China \\
\hline ND1 & EU414798 & EU414788/EU41485 & N. tabacum & China \\
\hline TFN & Y16925 & Y16926 & S. lycopersicum & Italy \\
\hline $\mathrm{Nt9}$ & D28779 & D28780 & S. lycopersicum & China \\
\hline PL-1 & AM183115 & AM183116 & S. lycopersicum & Spain \\
\hline New Delhi & GU111228 & GU111229 & S. lycopersicum & India \\
\hline VAL90/1 & - & AJ829779(CP) & S. lycopersicum & Spain \\
\hline $\mathrm{Cb}-7$ & DQ785470 & EF216867 & S. lycopersicum & China \\
\hline Phy & DQ412731 & DQ412732 & - & China \\
\hline Lucknow & - & EF153733 & Chrysanthemum morifolium & India \\
\hline IA & AB042293 & AB042294 & - & Indonesia \\
\hline CTL & EF213024 & EF213025 & Brassica chinensis & China \\
\hline Ixora & U20218 & U20219 & S. lycopersicum & Philippines \\
\hline SNK & FN552598 & - & C. sativus & Thailand \\
\hline- & AJ831395 & - & L. longiflorum & India \\
\hline Bal-In & - & $\mathrm{JF} 279609(\mathrm{CP})$ & C. melo & India \\
\hline MaS_Italy & - & JN593376(MP) & Mandevilla sanderi & Italy \\
\hline Vir56 & - & DQ006805(MP) & Thevetia nereifolia & Italy \\
\hline CMV-UP & - & DQ642017(MP) & Musa sp. & India \\
\hline S337 & - & AY871069(CP) & C. sativus & Iran \\
\hline SH17 & - & AY871068(CP) & C. sativus & Iran \\
\hline B13 & - & AY871070(CP) & C. sativus & Iran \\
\hline B23 & - & AY871071(CP) & C. sativus & Iran \\
\hline DI1 & - & DQ002876(CP) & C. реро & Iran \\
\hline EI1 & - & DQ002880(CP) & C. реро & Iran \\
\hline FI3 & - & DQ002883(CP) & C. реро & Iran \\
\hline GI1 & - & DQ002885(CP) & C. реро & Iran \\
\hline Q & X00985 & M21464 & Capsicum annum & Australia \\
\hline
\end{tabular}


A

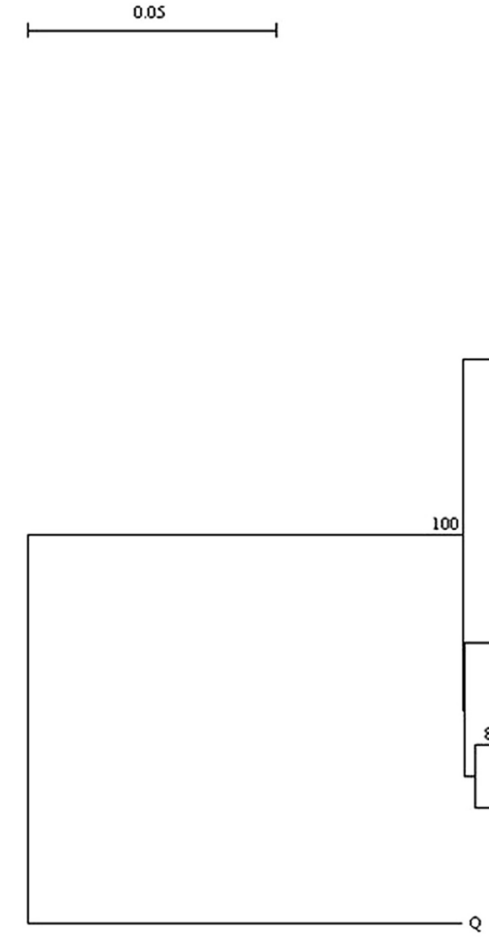

B

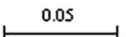

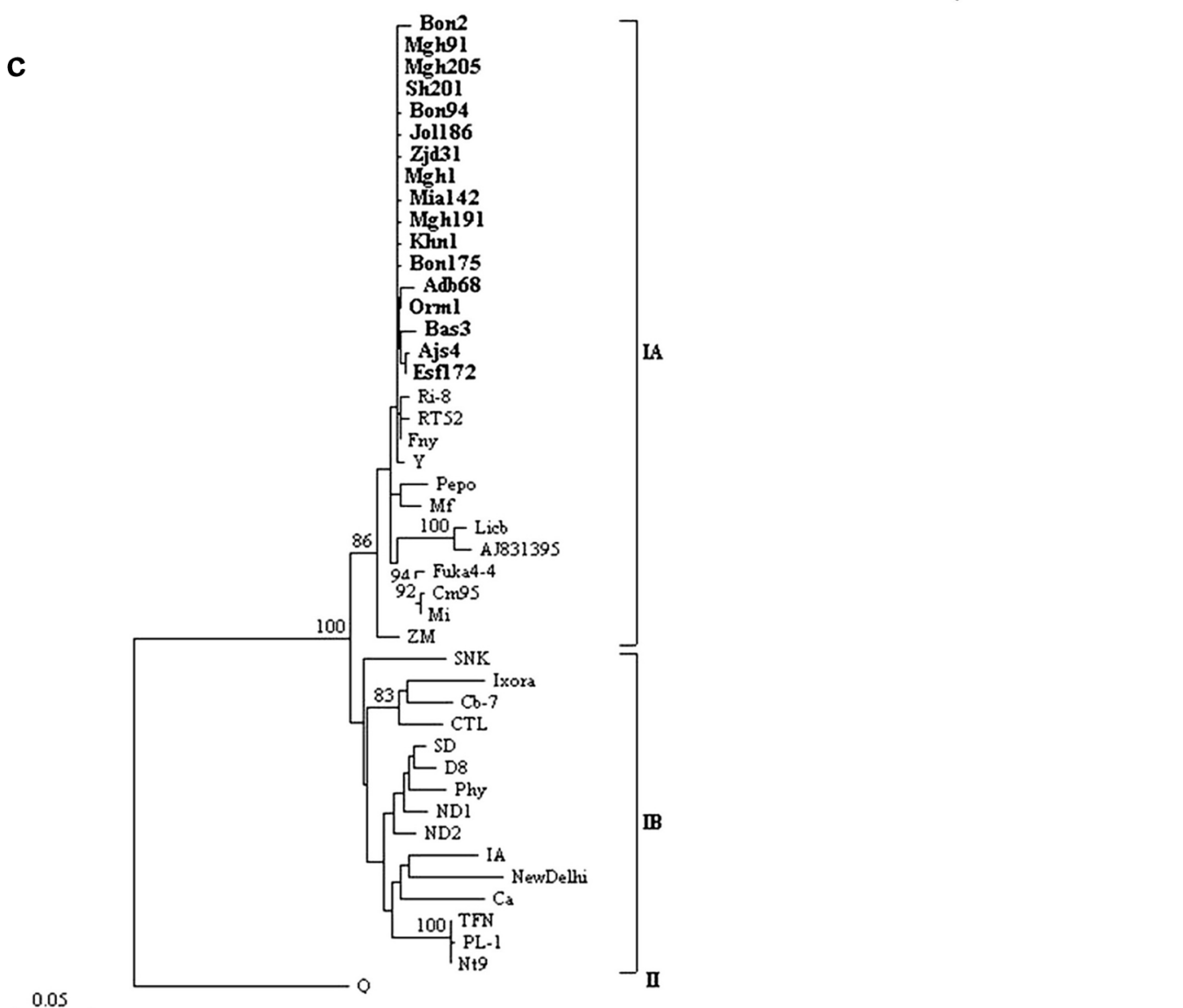

Fig. 3. Phylogenetic analysis of CMV including new isolates from Iran based on genes encoding the coat protein (A), movement protein (B) or $2 \mathrm{~b}$ protein $(\mathrm{C})$. Bootstrap values are shown above the branches $(>70 \%)$. New Iranian isolates are in bold. Strain Q of CMV, as a subgroup II member, was designated as the outgroup. 
sliding window and step-size options of 50 and 10, respectively, in DnaSP. Pi(a)/Pi(s) was $<1$ for all three genomic regions; however evidence of positive selection in the $\mathrm{CP}$, $\mathrm{MP}$ and $2 \mathrm{~b}$ genes was found. Nucleotide positions (midpoints) $154-233$ in the $2 b$ gene had the ratio value of $>1$ with a pick (the highest ratio value of 70.28) (Fig. 4). Although phylogenetic analysis of the Iranian isolates was done previously on the basis of the CP sequences (Bashir et al., 2006 and 2008), here we extended this analysis to the $2 \mathrm{~b}$ and MP sequences of isolates from different hosts and locations. This is important for studying plant virus evolution and understanding events such as recombination and reassortment that are major evolutionary forces for shaping virus populations including CMV population (Bonnet et al., 2005; Roossinck, 2002).

Phylogenies were inferred by the use of Phylip package version 3.65 (Felsenstein, 2004) and Treecon (Van de Peer and De Wachter, 1997) for parsimony- and distance-based trees, respectively. CMV- Q, a S-II strain, was designated as the outgroup. Finally, the selected tree was viewed by the Treeview program (Page, 1996). Because similar phylogenies were inferred based on the distance or parsimony method, regardless of whether nucleotide or amino acid data were used, only distance trees based on the nucleotide data are presented here. In the phylogenetic tree based on nucleotide sequences of the $\mathrm{CP}$ gene (Fig. 3A) the newly sequenced isolates of the present research including Bon175, Bon94, Jol186, Mgh91, Mgh191, Sh40, Sh44, and Zdj31, were placed in the S-IA cluster sharing 93-99\% nt (and 94$100 \%$ aa) identities with other S-IA isolates. These isolates, except for Jol186, together with two American isolates, CK54 and MD284, formed a subclade radiating from the SIA clade, with the highest nucleotide identity of $99 \%$ to the American isolate CK54. Previously reported CMV isolates from Iran such as DI1, EI1, FI3, GI1 (Bashir et al., 2008) were also placed with these isolates sharing 95-99\% nt (and 98-99\% aa) identities with them. Jol186 was placed with the remaining previously reported Iranian isolates B13, B23, S337 and SH17, (Bashir et al., 2006) in a different subclade with $99 \%$ similarity to ZM (Korean isolate). Isolates Ajs4, Bas3, Esf172 and Khn1 together with Bal-ln isolate from India formed a subclade radiating from the S-IB clade sharing 99\% identity to isolate CMVG10 from Egypt. Isolates (Ajs4, Bas3, Esf172, and Khn1) that were placed in S-IB clade on the basis of the biological studies were apparently more virulent than (Bon175, Mgh91, Mgh191 and Jol186) isolates in S-IA clade. Isolates in S-IA clade induced mosaic on squash, mild shoestring on tomato and mild mosaic on tobacco cultivars and $N$. benthamiana. This is also in agreement with a previous report that S-IB isolates are more virulent than S-IA isolates (Du et al., 2007). The CP nucleotide and amino acid identities of isolates characterized in this study and that of other S-IB isolates were both $91-99 \%$.

Distribution of CMV isolates into different subgroups on the MP-based phylogenetic tree (Fig. 3B) agreed with that in the CP-based tree. Iranian S-IA isolates had the highest similarity (99\%) with isolate Pepo. Isolate Jol186 with 99\% identity to several non-Asian isolates, such as the Italian isolate $\mathrm{Ri}-8$, formed a subclade within the $\mathrm{S}$-IA clade, in the most distal position to the Iranian isolates. The nucleotide and amino acid identities of the MP region of the newly characterized isolates to other S-IA isolates were 96-99\% and $99-100 \%$, respectively. Similar to what was seen in the CP-based phylogenetic tree, isolates Ajs4, Bas3, Esf172 and Khn1 with 92-96\% nt (94-97\% aa) identities to other isolates were placed in S-IB. The closest previously reported isolate to these Iranian isolates was CMV-UP with $96 \%$ identity. In the phylogenetic tree based on the $2 \mathrm{~b}$ gene (Fig. 3c), 29 out of 45 analyzed isolates including seventeen Iranian isolates were placed in S-IA with 90-99\% nt identities to previously reported S-IA members. However, in the MP- or CP-based tree these isolates were divided into S-IA and S-IB. The most similar strain to the Iranian isolates in the $2 \mathrm{~b}$ gene was Fny with $99 \%$ nt identity. The nucleotide and amino acid identities between the newly reported Iranian isolates were $91-99 \%$ and $94-100 \%$ for the CP gene, $92-99 \%$ and $96-100 \%$ for the MP gene, and $98-99 \%$ and $98-99 \%$ at the $2 b$ gene.

When nucleotide sequences were used as the basis of the analysis, subgroup affiliation of all the previously reported isolates remained the same on the CP-, MP- or 2b-based trees with the exception of isolate D8. This isolate belonged to S-IA on the CP- and MP-based trees but to S-IB on the 2b-based tree possibly because of reassortment in CMV isolates, a phenomenon which has already been reported in strains of CMV (Lin et al., 2004; Liu et al., 2009; Roossinck, 2002). All the Iranian isolates characterized in this study were divided into S-IA (6 isolates) and S-IB (4 isolates) on the basis of $\mathrm{CP}$ and MP sequences, but were placed in S-IA on the $2 b$ tree. This suggested that the $2 b$ gene does not co-evolve with the other genomic regions.

Generally, the evolution rate of the $2 b$ gene is known to differ from the other genomic regions (Liu et al., 2009; Lin et al., 2004). However, others (Liu et al., 2009; Roossinck, 2002) argued that the $2 b$ was the most diverse genomic part of CMV. Pi(a)/Pi(s) for the $2 \mathrm{~b}$ genes of Iranian isolates was even less that of the MP and CP genes. However, a section of the $2 b$ region for the Iranian isolates, amino acid positions 52-78 proximal to the section reported for group $\alpha$, was found to possess the ratio value of greater than 1 (Figure 4). Therefore, the Iranian CMV population appears similar to group $\alpha$ isolates of California (Lin et al., 2004) in respect to the diversity of the $2 \mathrm{~b}$ gene. We speculate that 


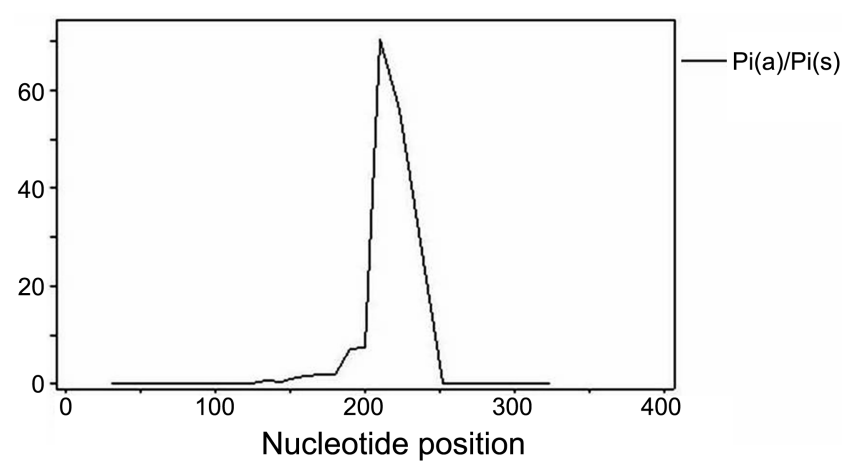

Fig. 4. A curve representing evidence of positive selection along alignment of the $2 \mathrm{~b}$ gene from seventeen CMV isolates from Iran. The Pi(a)/Pi(s) ratios were generated by DnaSP version 5.10 .01 by the use of sliding window and step size options of 50 and 10 , respectively. The region between nucleotide positions (midpoints) 154 and 233 has the ratio value of $>1$. The highest value (70.28) belongs to position 210 .

such isolates might have passed through a bottleneck when the virus was introduced into the country and thus resulted from a founder effect by a common ancestor that colonized and spread only recently in the region.
It also appeared that the Iranian isolates, in the particular the S-IB isolates, had the highest similarities to the Asian isolates of CMV on the basis of the CP and MP sequences. Most S-IB isolates are distributed in Asia whereas S-IA and S-II are found worldwide (Palukaitis and Zaitlin, 1997; Roossinck, 2002). On the other hand, the Iranian S-IA isolates had maximum similarities to the USA isolates, therefore, it may be concluded that the Iranian isolates have different origins. Some of them including Ajs4, Bas3, Esf172 and $\mathrm{Khn} 1$ which belong to S-IB, probably originated in Asia and evolved further in Iran. These isolates appear to have evolved earlier than other Iranian isolates as shown by their closer phylogenetic positions to S-II (Fig. 3). Thus, $\mathrm{S}-\mathrm{IB}$ isolates are presumed to be ancestors for S-IA isolates (Roossinck et al., 1999). Iranian S-IA isolates have probably originated from different locations other than Asia and then spread through seeds in Iran.

In summary, the outcome of this study drew a tentative link between genotypes and biological properties of the representative isolates. The frequent occurrence of S-I members was again demonstrated. Phylogenetic positions of the newly characterized isolates remained the same

Table 3. Characteristics of new Iranian isolates of CMV reported in this study

\begin{tabular}{|c|c|c|c|c|c|c|c|c|c|}
\hline \multirow{2}{*}{ Isolate $^{\mathrm{a}}$} & \multirow{2}{*}{ Origin } & \multirow{2}{*}{ Phenotype $^{\mathrm{b}}$} & \multicolumn{3}{|c|}{ PCR Detection } & \multirow{2}{*}{ Subgroup $^{c}$} & \multicolumn{3}{|c|}{ Phylogenetic position } \\
\hline & & & $2 b$ & $\mathrm{cp}$ & $\mathrm{mp}$ & & $2 b$ & $\mathrm{cp}$ & $\mathrm{mp}$ \\
\hline Orm & Orumieh & n.t. & + & + & n.t $\mathrm{t}^{\mathrm{d}}$ & I & $\mathrm{IA}^{\mathrm{e}}$ & n.t. & n.t. \\
\hline Jol186 & Jolfa & SM & + & + & + & I & IA & IA & IA \\
\hline Bon94 & Bonab & n.t. & + & + & + & I & IA & IA & IA \\
\hline Mgh91 & Maragheh & SM & + & + & + & I & IA & IA & IA \\
\hline Mgh205 & Maragheh & n.t. & + & + & n.t. & I & IA & n.t. & n.t. \\
\hline Bon175 & Bonab & SM & + & + & + & I & IA & IA & IA \\
\hline Esf172 & Esfahalan & $\mathrm{N}$ & + & + & + & I & IA & IB & IB \\
\hline Mgh191 & Maragheh & MM & + & + & + & I & IA & IA & IA \\
\hline Sh201 & Shabestar & n.t. & + & + & + & I & IA & n.t. & n.t. \\
\hline Zdj31 & Zanjirabad & n.t. & + & + & + & I & IA & IA & IA \\
\hline Mia142 & Mianeh & n.t. & + & + & + & I & IA & n.t. & n.t. \\
\hline Bas3 & Basmenj & $\mathrm{N}$ & + & + & + & I & IA & IB & IB \\
\hline Bon2 & Bonab & n.t. & + & + & + & I & IA & n.t. & n.t. \\
\hline Khnl & Khodafrin & $\mathrm{N}$ & + & + & + & I & IA & IB & IB \\
\hline Mgh1 & Maraghe & n.t. & + & + & + & I & IA & n.t. & n.t. \\
\hline Ajs4 & Ajabshyr & $\mathrm{N}$ & + & + & + & I & IA & IB & IB \\
\hline Adb68 & Ardabil & n.t. & + & + & n.t. & I & IA & n.t. & n.t. \\
\hline $\operatorname{Sh} 40$ & Shabestar & n.t. & n.t. & + & + & I & n.t. & IA & n.t. \\
\hline $\mathrm{Sh} 44$ & Shabestar & n.t. & n.t. & + & + & I & n.t. & IA & n.t. \\
\hline
\end{tabular}

a isolates Orm, Bon94, Esf172, Bon2, Khn1, Mgh1, Ajs4 and Adb68 were from tomato; Jol186, and Mgh91 from muskmelon; Mgh205, Bon175, Sh201, Zdj31, Bon2 and Bas3 from cucumber; Mgh191, Sh40 and Sh44 from squash

${ }^{\mathrm{b}}$ Symptoms on squash and tomato test plants, $\mathrm{SM}=$ severe mosaic on squash and no or mild shoestring on tomato, $\mathrm{N}=$ necrosis on squash with severe shoestring on tomato, $\mathrm{MM}=$ mild mosaic on squash and tomato

${ }^{\mathrm{c}}$ Determined by MspI digestion of the PCR products resulting from the use the CP primers.

${ }^{\mathrm{d}}$ n.t. $=$ not tested.

${ }^{\mathrm{e}} \mathrm{IA}$ and IB refer to CMV subgroups IA and IB 
regardless of whether MP or CP sequences were used, but differed when the $2 b$ sequences were set as the basis of the analysis. Results from this study suggested that the Iranian isolates are derived from a common recent ancestor that had passed through a bottleneck event.

\section{Acknowledgements}

We like to thank Dr. Peter Palukaitis for careful review of this paper.

\section{References}

Bashir, N. S., Kolhar, M. R. and Zarghani, S. N. 2006. Detection, differentiation and phylogenetic analysis of cucumber mosaic virus isolates from cucurbits in the northwest region of Iran. Virus Genes 32:277-288.

Bashir, N. S., Nematollahi, S. and Torabi, E. 2008. Cucumber mosaic virus subgroup IA frequently occurs in the northwest IRAN. Acta Virol. 52:237-242.

Boccard, F. and Baulcombe, D. 1993. Mutational analysis of cisacting sequences and gene function in RNA3 of cucumber mosaic virus. Virology 193:563-578.

Bonnet, J., Fraile A, Sacristán, S., Malpica, J. M. and García-Arenal, F. 2005. Role of recombination in the evolution of natural populations of Cucumber mosaic virus, a tripartiteRNA plant virus. Virology 332:359-368.

Bujarski, J., Figlerowicz, M., Gallitelli, D., Roossinck, M. J. and Scott, S. W. 2012. Family Bromoviridae. In: Virus Taxonomy: Classification and Nomenclature of Viruses; Ninth Report of the International Committee on Taxonomy of Viruses, ed. by A. M. Q. King, M. J. Adams, E. B. Carstens and E. J. Lefkowitz, pp. 965-976. Elsevier Academic Press, Waltham, MA USA.

Choi, S. K., Palukatis, P., Min, B. E., Lee, M. Y., Choi, J. K. and Ryu, K. H. 2005. Cucumber mosaic virus 2a polymerase and movement proteins independently affect both virus movement and the timing of symptom development in zucchini squash. $J$. Gen. Virol. 86:1213-1222.

Chung, C. T., Niemela, S. A. and Miller, R. H. 1989. One-step preparation of competent Escherichia coli: transformation and storage of bacterial cells in the same solution. Proc. Natl Acad. Sci. USA 86:2172-2175.

Clark, M. F. and Adams, A. N. 1977. Characteristics of the microplate method of enzyme-linked immunosorbent assay for the detection of plant viruses. J. Gen. Virol. 34:475-483.

Ding, S. W., Anderson, B. J., Haase, H. R. and Symons, R. H. 1994. New overlapping gene encoded by the Cucumber mosaic virus genome. Virology 198:593-601.

Du, Z. Y., Chen, F. F., Liao, Q. S., Zhang, H. R., Chen, Y. F. and Chen, J. S. 2007. 2b ORFs encoded by subgroup IB strains of Cucumber mosaic virus induce differential virulence on Nicotiana species. J. Gen. Virol. 88:2596-2604.

Felsenstein, J. 2004. PHYLIP (Phylogeny Inference Package) Version 3.65. Distributed by the author. Department of
Genome Sciences, University of Washington, Seattle.

Gallitelli, D. The ecology of Cucumber mosaic virus and sustainable agriculture. 2000. Virus Res. 71:9-21.

Hayes, R. J. and Buck, K. W. 1990. Complete replication of a eukaryoticvirus RNA in vitro by a purified RNA-dependent RNA polymerase. Cell 63:363-368.

Huppert, E., Szilassy, D., Salanki, K., Diveki, Z. and Balazs, E. 2002. Heterologous movement protein strongly modifies the infection phenotype of cucumber mosaic virus. J. Virol. 76:3554-3557.

Lewsey, M. G., Surette, M., Robertson, M., Robertson, F. C., Ziebell, H., Choi, S. H., Ryu, K. H., Canto, T., Palukaitis, P., Payne, T., Walsh, J. A. and Carr, J. P. 2009. The Role of the Cucumber mosaic virus 2b Protein in Viral Movement and Symptom Induction. Mol. Plant-Microbe Interact. 22:642654.

Lewsey, M. G., Gonzalez, I., Kalinina, N. O., Palukaitis, P., Canto, T. and Carr, J. P. 2010. Symptom induction and RNA silencing suppression by the Cucumber mosaic virus $2 \mathrm{~b}$ protein. Plant Signal. Behav. 5:705-708.

Li, H. W., Lucy, A. P., Guo, H. S., Li, W. X., Ji, L. H., Wong, S. M. and Ding, S. W. 1999. Strong host resistance targeted against a viral suppressor of the plant gene silencing defense mechanism. EMBO J. 18:2683-2691.

Librado, P. and Rozas, J. 2009. DnaSP v5: A software for comprehensive analysis of DNA polymorphism data. Bioinformatics 25:1451-1452.

Lin, H. Z., Rubio, L., Smythe, A. B. and Falk, B. W. 2004. Molecular population genetics of Cucumber mosaic virus in California: evidence for founder effects and reassortment. J. Virol. 78:6666-5575

Liu, Y. Y., Yu, S. L., Lan, Y. F., Zhang, C. L., Hou, S. S., Li, X. D., Chen, X. Z. and Zhu, X. P. 2009. Molecular variability of five Cucumber mosaic virus isolates from china. Acta Virol. 53:89-97.

Nicholas, K. B., Nicholas, H. B. Jr. and Deerfield, D. W. II. 1997. GeneDoc: Analysis and Visualization of Genetic Variation, EMBNEW.NEWS 4:14.

Page, R. D. M. 1996. Treeview - An application to display phylogenetic trees on personal computers. Comput. Appl. Biosci. 124:357-358.

Palukaitis, P., Roossinck, M. J., Dietzgen, R. G. and Francki, R. I. B. 1992. Cucumber mosaic virus. Adv. Virus Res. 41:281-348.

Palukaitis, P. and Zaitlin, M. 1997. Replicase-mediated resistance to plant virus disease. Adv. Virus Res. 48:349-377.

Palukaitis, P. and Garcia-Arenal, F. 2003. Cucumoviruses. Adv. Virus Res. 62: 241-323.

Perry, K. L., Zhang, L., Shintaku, M. H. and Palukaitis, P. 1994. Mapping determinants in Cucumber mosaic virus for transmission by Aphis gossypii. Virology 205:591-595.

Rizos, H., Gunn, L. V., Pares, R. D. and Gillings, R. M. 1992. Differentiation of Cucumber mosaic virus isolates using the polymerase chain reaction. J. Gen. Virol. 73:2099-2103.

Roossinck, M. J., Zhang, L. and Hellwald, K. H. 1999. Rearrangements in the $5^{\prime}$ nontranslated region and phylogenetic analyzes of Cucumber mosaic virus RNA 3 indicate radial 
evolution of three subgroups. J. Virol. 73:6752-6758.

Roossinck, M. J. 2001. Cucumber mosaic virus as a model for RNA virus evolution. Mol. Plant Pathol. 2:59-63.

Roossinck, M. J. 2002. Evolutionary history of Cucumber mosaic virus deduced by phylogenetic analyses. J. Virol. 76:33823387.

Rowhani, A., Chay, C., Golino, D. A. and Falk, W. 1993. Development of a polymerase chain reaction technique for the detection of Grapevine fanleaf virus in a grapevine tissue. Phytopathology 83:749-753.

Rychlik, W. 1994. Oligo Primer Analysis Software version 5.0. Published by National Biosciences Inc., MN, USA.

Shi, B. J., Palukaitis, P. and Symons, R. H. 2002. Differential virulence by strains of Cucumber mosaic virus is mediated by the 2b gene. Mol. Plant-Microbe Interact. 15:947-955.

Shintaku, M. H., Zhang, L. and Palukaitis, P. 1992. A single amino acid substitution in the coat protein of Cucumber mosaic virus induces chlorosis in tobacco. Plant Cell 4:751-
757.

Soards, A. J., Murphy, A. M., Palukaitis, P. and Carr., J. P. 2002.Virulence and differential local and systemic spread of Cucumber mosaic virus in tobacco are affected by the CMV 2b protein. Mol. Plant-Microbe Interact. 15:647-653.

Sugiyama, M., Sato, H., Karasawa, A, Hase, S., Takahashi, H. and Ehara, Y. 2002. Characterization of symptom determinants in two mutants of Cucumber mosaic virus $\mathrm{Y}$ strain, causing distinct mild green mosaic symptoms in tobacco. Physiol. Mol. Plant Pathol. 56:85-90.

Suzuki, M., Kuwata, S., Masuta, C. and Takanami, Y. 1995. Point mutations in the coat protein of Cucumber mosaic virus affect symptom expression and virion accumulation in tobacco. $J$. Gen. Virol. 76:1791-1719.

Van de Peer, Y. and De Wachter, R. 1997. Construction of evolutionary distance trees with TREECON for Windows: accounting for variation in nucleotide substitution rate among sites. Comput. Appl. Biosci. 13:227-230. 